\title{
セラミックスの高温動疲労特性
}

\author{
山内幸彦・酒井清介・伊藤勝 $\cdot$ 大司達樹 \\ 兼松渉・伊藤正治 \\ (名古屋工業技術試験所，462 名古屋市北区平手町 1-1)
}

\section{Dynamic Fatigue Behavior of Ceramics at Elevated Temperatures}

\author{
Yukihiko YAMAUCHI, Seisuke SAKAI, Masaru ITO, Tatsuki OHJI, \\ Wataru KANEMATSU and Shoji ITO
}

(Government Industrial Research Institute, Nagoya, 1-1, Hirate-cho, Kita-ku, Nagoya-shi

\begin{abstract}
The dynamic fatigue tests of nine structural ceramics were carried out at temperatures ranging from $800^{\circ} \mathrm{C}$ to $1500^{\circ} \mathrm{C}$ in vacuum. The same tests in air were conducted for two ceramics. In ceramics which has a glassy phase in grain boundaries, cracks propagate through grain boundaries due to softening of the glassy phase. A fatigue parameter of ceramics at elevated temperatures is degraded when $\mathrm{MgO}$ is used as a sintering additive. In reaction sintered $\mathrm{Si}_{3} \mathrm{~N}_{4}$ and $\mathrm{HP}$-SiC with $\mathrm{B}$ and $\mathrm{C}$ additives, a subcritical crack growth is not observed but the bending strength of HP-SiC is degraded due to the generation of pores by surface oxidation. It seems that life-time of $\mathrm{HP}-\mathrm{Si}_{3} \mathrm{~N}_{4}$ under the static load is predictable from its dynamic fatigue behaviour.

[Received August 10, 1989; Accepted November 22, 1989]
\end{abstract}

Key-words : Silicon nitride ceramics, Silicon carbide ceramics, Dynamic fatigue test, Slow crack growth, Oxidization

\section{1. 緒 言}

セラミックスは高温での機械的特性に優れているた め, 高温構造材料としての利用が期待されている. しか しセラミックスの強度特性にはまだ不明な点が多く, セ ラミックスに適した設計基準を構築するためには体系的 な強度デー夕の収集を行い, その破壊機構を明らかにす る必要がある. 特に欠陷の発生, 成長機構の解明は, 七 ラミックス部材の寿命予測に不可欠である. 前報 10 種類の構造材料用セラミックスの室温動疲労試験を 実施し, 室温におけるき裂進展機構について考察した. 本報告では，前報で用いたものと同じセラミックス 9 種 類の高温動疲労試験を実施し, 高温におけるセラミック スのき裂進展機構について考察した. また, 試料の表面 酸化が動疲労試験結果に及ぼす影響についても検討し た. 更に一部の試料について動疲労特性から予測した一 定荷重下での寿命と静疲労試験結果を比較検討した.

\section{2. 実験方法}

\section{1 試料の加工}

武料に用いたセラミックスは，前報 ${ }^{1)}$ で使用したもの と同じ窒化ケイ素セラミックス 5 種類 $(\mathrm{N} 1 \sim \mathrm{N} 5$, 使 用する記号は前報と同一) と炭化ケイ素セラミックス 4 種類（C 1 C 4 ）である. N 1 及び C 1 は反応焼結体,
$\mathrm{N}_{2}$ 〜 N 4 及び C $2, \mathrm{C} 3$ は常圧焼結体, N 5 及び C 4 は ホットプレス材であり, 焼結助剤として N 2 には $\mathrm{MgO}$, $\mathrm{CeO}_{2}, \mathrm{SrO}, \mathrm{ZrO}_{2}$ が, $\mathrm{N} 3$ には $\mathrm{MgO}$ と $\mathrm{Al}_{2} \mathrm{O}_{3}$ が, $\mathrm{N}_{4}$ 及び $\mathrm{N} 5$ には $\mathrm{Al}_{2} \mathrm{O}_{3}$ と $\mathrm{Y}_{2} \mathrm{O}_{3}$ が, $\mathrm{C} 2$ 及び $\mathrm{C} 3$ には $\mathrm{Al}_{2} \mathrm{O}_{3}$ が， C 4 にはBとCがそれぞれ用いられている. 試料の化学分析結果と密度については前報”を参照して いただきたい。試験片は各材料 1 枚の焼結体ブロックか ら切り出し, 窒化ケイ素セラミックスに対しては\#400 の, 炭化ケイ素セラミックスに対しては\#600のダイヤ モンド砥石を用いて試験片長手方向に平行に研削加工し た後, 各コーナーを\#800 のダイヤモンドディスクで面 取りして作製した. 試験片の最終形状は長さ $38 \mathrm{~mm}$, 幅 $4 \mathrm{~mm}$ ，厚さ $3 \mathrm{~mm}$ である.

\section{2 真空中における試験}

一般に動疲労試験はガラス材等の応力腐食特性を測定 する方法であるが，材料のき裂進展速度 $V$ とき裂先端 における応力拡大係数 $K_{\mathrm{I}}$ との間に

$$
V=A \cdot K_{1}^{n} \quad(A: \text { 定数 })
$$

の関係が成り立てば疲労指数 $n$ を評価する方法として 用いることができる. 過去の文献例 ${ }^{21,3)}$ では, 窒化ケイ 素セラミックスの高温における $K_{\mathrm{I}}-V$ 特性はき裂進展速 度が $10^{-6} \mathrm{~m} / \mathrm{s}$ 以下の領域でほぼ（1）式を満足してお り, 動疲労試験によるセラミックスの高温疲労指数の評 


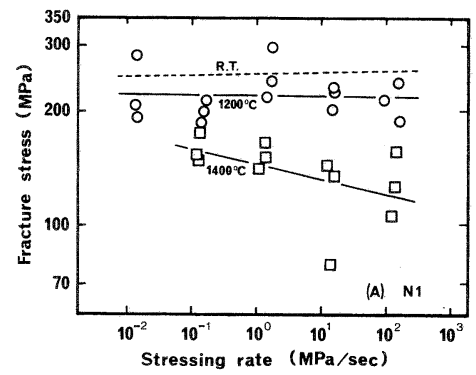

(A)

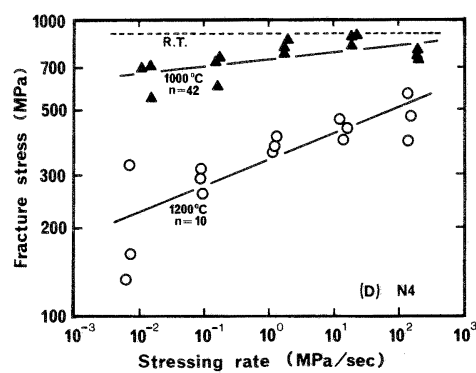

(D)

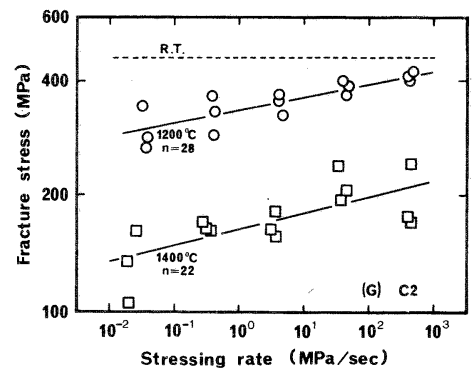

(G)

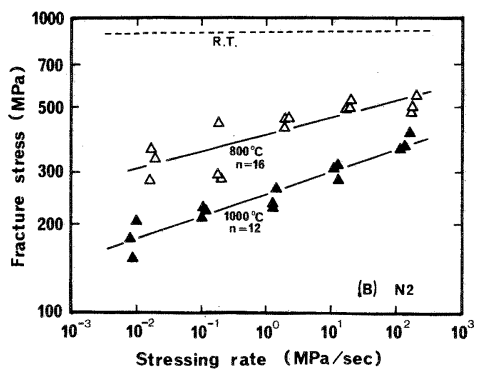

(B)

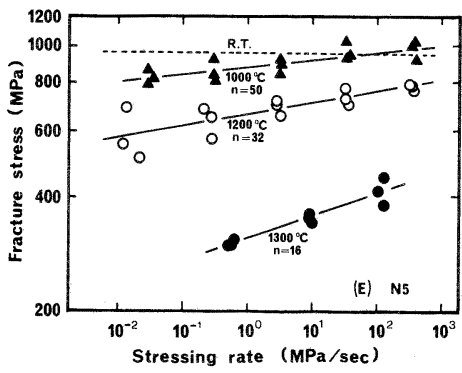

(E)

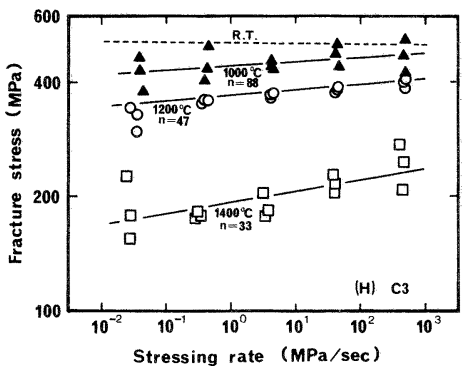

( $\mathrm{H})$

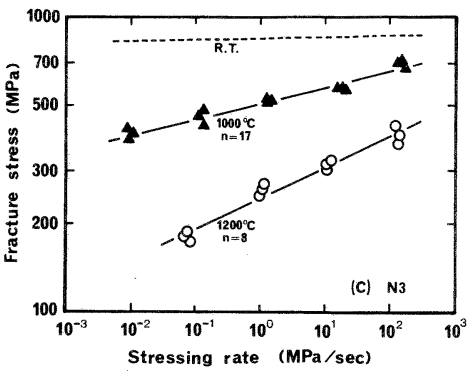

(C)

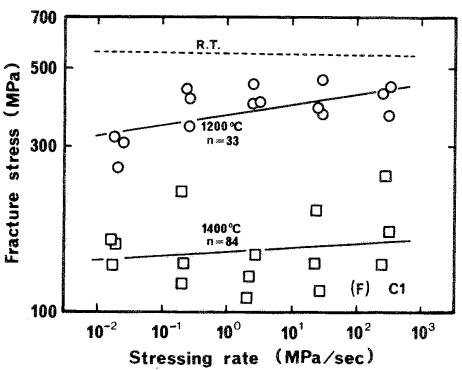

( F)

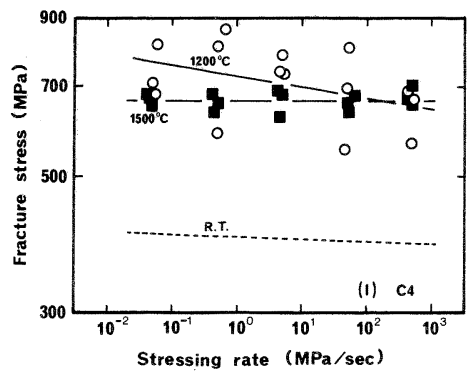

( I )

Fig. 1. Results of dynamic fatigue tests in vacuum.

価が可能であると考えられる.

今回行った試験の雾囲気は, $800^{\circ} \sim 1500^{\circ} \mathrm{C}, 10^{-5}$ Torr の真空である. 試験温度は一つの試料につき二水 準以上設定したが, その選択基準は曲げ強度の落ち始め た直後の温度とそれより $200^{\circ} \mathrm{C}$ 高い温度とした. また, 曲げ強度が高温で低下しない材料については $1500^{\circ} \mathrm{C}$ を 最高設定温度とした.試験片の昇温は,タングステンヒー ターを用いてモリブデン製曲げ治具, 上下ロッドを含む 系全体を均熱することにより行った. その場合, まず炉 の内部を $10^{-4}$ Torr 以下の真空に引き, 約 10 分間で試 験温度まで加熱した後, 均熱を得るために 10 分間無負 荷で保持した。

動疲労試験は前述の試験片の 3 点曲げ強度を, 外部ス パン $30 \mathrm{~mm}$ ，クロスヘッド速度 $5,0.5,0.05,0.005$, $0.0005 \mathrm{~mm} / \mathrm{min}$ の条件で測定することにより行った. 各クロスヘッド速度における試験片数は 3 本である. 試 料の疲労指数 $n$ は, 3 点曲げ試験における時間-荷重曲
線から求めた応力速度 $\dot{\sigma}$ と破断応力 $\sigma_{\mathrm{f}}$ の関係を $\log$ $\log$ 平面上で最小二乗法により直線近似し，その直線の 傾きから

$$
\sigma_{\mathrm{f}}=c \cdot \dot{\sigma}^{(1 / n+1)} \quad(c: \text { 定数 })
$$

に従って求めた。この場合，（2）式が成り立つには負 荷期間全体にわたって応力速度が一定である，き裂の形 状係数がき裂の成長に伴って変化しない等の仮定が必要 であるため, 弾性変形領域から大きく外れて破壊した試 験片，形状係数が一定と見なせないほど大きなき裂成長 を示した試験片のデータは除外した。その場合の判断基 準は, 試験終了後に試験片が目視では変形していないこ と, 荷重-時間曲線における荷重速度の変化が直線部分 に対して $20 \%$ 以下であることとした，また，き裂成長 の限度は，欠陥形状が半円形であると仮定し，試験片表 面におけるき裂先端の形状係数変化が約 $10 \%$ 以下にな るよう, $1 \mathrm{~mm}$ 程度の深さまでとした.

\section{3 大気中における試験}



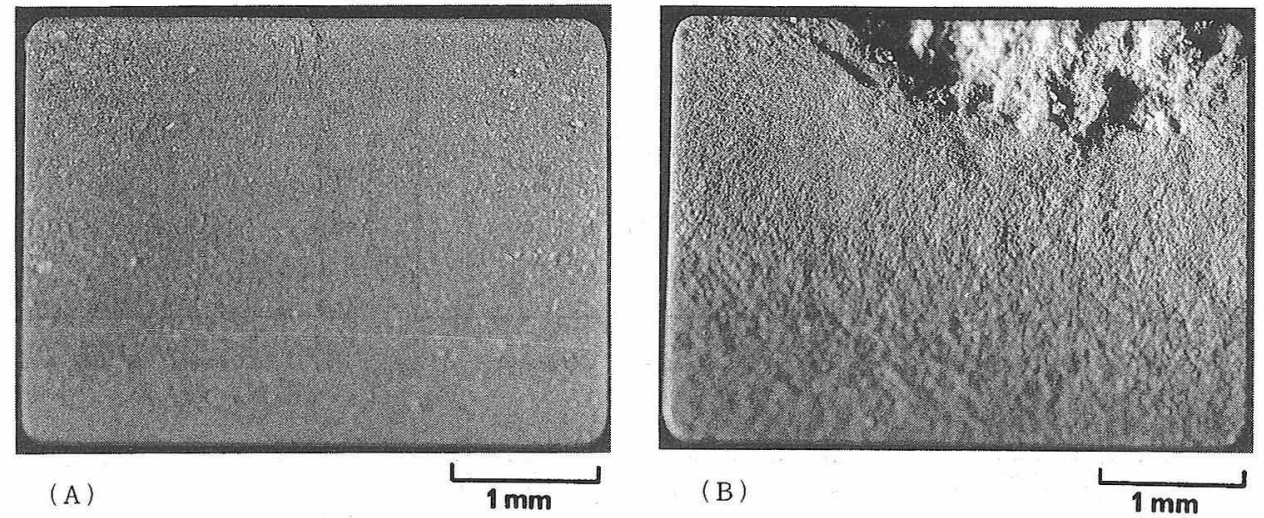

Fig. 2. Fracture surfaces of $\mathrm{N} 2$ specimens failed by dynamic fatigue test with crosshead speed (A) $5 \mathrm{~mm} / \mathrm{min}$ and (B) $0.0005 \mathrm{~mm} / \mathrm{min}$ at $1000^{\circ} \mathrm{C}$ in vacuum.
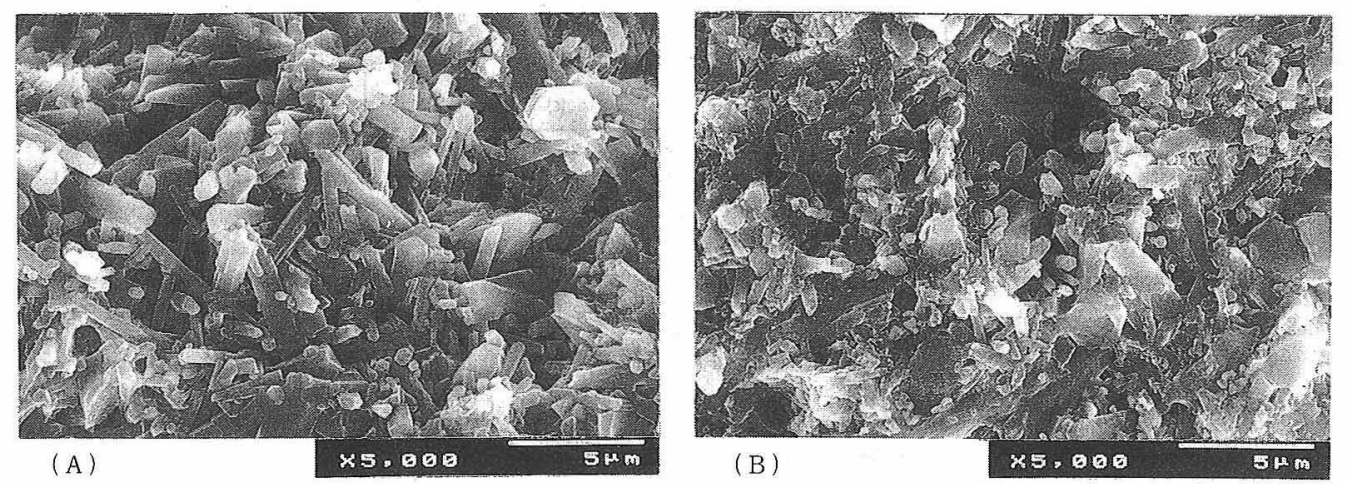

Fig. 3. SEM photographs of (A) slow crack growth region and (B) rapid fracture region on fracture surface of $\mathrm{N} 2$ specimen (Fig. 2(B)).

試料 N 5 と C 4 については前述の真空中での動疲労 試験之同様の試験を大気中でも行った。この大気中の試 験には $\mathrm{SiC}$ 製 3 点曲げ治具及び上下ロッドを用い, 二 ケイ化モリブデンヒーターにより加熱した．昇温速度は $30^{\circ} \mathrm{C} / \mathrm{min}$ であり，設定温度に到達後均熱を得るために 10 分間無負荷で保持して試験を開始した。

\section{3. 結果と考察}

\section{1 真空中における動疲労特性}

真空中での動疲労試験結果を図 1 (A) 〜 (I) に示す. 試料 $\mathrm{N} 2 \sim \mathrm{N} 5$ 及び C $2, \mathrm{C} 3$ の破壊応力，疲労指数は， 試験温度の上昇に伴って大きく低下した。これらの材料 には焼結助剂として $\mathrm{Al}_{2} \mathrm{O}_{3}$ や $\mathrm{MgO}$ 等の酸化物が用いら れており，その粒界にはガラス相が存在することを一部 の試料 (N2，N 5， C 2) で確認している。このガラス 相は $1000^{\circ} \mathrm{C}$ 前後から軟化し始好る゙)こから，これら の試料の高温におけるき裂成長は粒界ガラス相の強度低 下を原因としていると思われる. 図 2 は今回用いた試料 の中でも大きな強度及び疲労指数の低下を示した N 2 の, $1000^{\circ} \mathrm{C}$, クロスヘッド速度 $5 \mathrm{~mm} / \mathrm{min}$ の条件で破 壞した試験片 $(\mathrm{A})$ と, $1000^{\circ} \mathrm{C}$, クロスヘッド速度
$0.0005 \mathrm{~mm} / \mathrm{min}$ の条件で破壊した試験片（B）の破断 面の光学顕微鏡写真であるが, 応力速度の速い条件で破 壞した $(\mathrm{A})$ にはほとんどき裂成長が認められないのに 対し，応力速度の遅い条件で破壊した（B）には大きな き裂成長の痕跡が認妨られる。また，図 $3(\mathrm{~A})$ と $(\mathrm{B})$ はそれそれ図 2 (B) のゆっくりとしたき裂成長領域と， 高速破壊領域を走查型電子顕微鏡 (SEM) により観察 したものであるが，高速破壊領域では若干の粒内破壊が 認められるのに対し，ゆっくりとしたき裂成長を起こし た領域はほぼ完全に粒界破壤である。

またクロスヘッド速度の速い条件で破壊した試験片破 面の形態は，クロスヘッド速度の遅い条件で破壊した試 験片の高速破壊領域（図 $3(\mathrm{~B})$ ) とほぼ同一であり，多 少粒内破壊が目立つ.これらの破面観察から粒界のき裂 進展に対する抵抗はき裂進展速度の影響を受けると考元

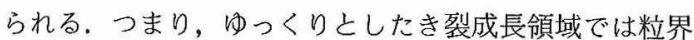
の割れに対する抵抗が小さく，き裂は粒界を進むが，高 速破壊領域では粒界割れがき裂開口に応答できず，割れ に対する抵抗が増加する。そその結果比較的弱い粒子にお いて粒内割れを生じたのではないのかと思われる.

以上の結果から，粒界にガラス相が存在するセラミッ 


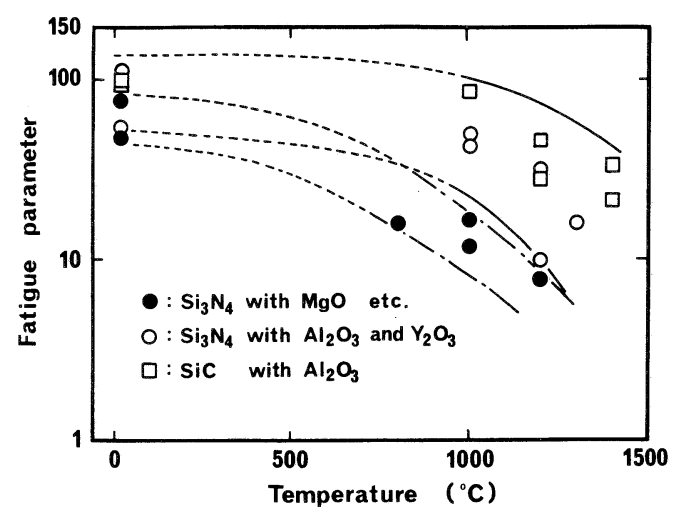

Fig. 4. Temperature dependence of fatigue parameter.

クスの高温におけるき裂成長は, ガラス相の粘性低下に よる粒界割れが主因と考えられる.

図 4 は酸化物を焼結助剤としている試料の温度と疲労 指数の関係を示したものである.この図において室温疲 労指数は前報 ${ }^{1}$ 室温大気中での測定結果を用いた。図 4 では今回用いた試料を二つのグループに分けることがで きる。稘結助剤に $\mathrm{Al}_{2} \mathrm{O}_{3}$ と $\mathrm{Y}_{2} \mathrm{O}_{3}$ を用いている $\mathrm{N} 4$ と $\mathrm{N}$ 5 及び $\mathrm{Al}_{2} \mathrm{O}_{3}$ を, 用いている $\mathrm{C} 2$ と $\mathrm{C} 3$ の疲労指数の温 度依存性はほぼ同じであるのに対し, $\mathrm{MgO}$ を焼結助剤 に用いている N 2 と N 3 の疲労指数は $\mathrm{Al}_{2} \mathrm{O}_{3}$ 助剤系七ラ ミックスの疲労指数に比べて低温度で低下し始め, その 絶対值も小さい.これは, N 2 及びN 3 のガラス相が $\mathrm{Mg}$ を含むため, $\mathrm{Mg}$ を含まない他のセラミックスのガ ラス相に比べて低温度で軟化し始めることが原因と考え られる。

次に反応焼結体 (N 1， C 1) 及び非酸化物を焼結助 剤としているセラミックス (C 4) の動疲労試験結果を みると N 1, C 4 については高温においても長時間負荷 による強度低下が認められない。これらの試料の酸素含 有量は比較的少なく $(1 \sim 2 \mathrm{wt} \%)$ ，その粒界にはガラス 相のような第 2 相がほとんど存在しないかあるいは第 2 相が存在しても高温強度の高い非晶質であると思われ る5). また光学顕微鏡による破面観察の結果, N 1, C 4 試験片には図 2 (B) に示したようなき裂成長の痕跡は 認められなかった。したがってこれらの試料では粒界に ガラス相が存在するセラミックスでのような粒界割れに よるき裂成長が起こらず, 応力速度を小さくしても強度 が低下しなかったと考えられる。

C 1 は N 1 と同様反応焼結体であり, 酸素含有量も少 ない（約 $1.6 \mathrm{wt} \%)$ 試料であるが，温度の上昇に伴っ て曲げ強度が低下し， $1200^{\circ} \mathrm{C}$ では若干のき裂成長が認 められた.これは，この試料にかなりの金属 Si が残留 しており (約 $10 \mathrm{wt} \%)$ ，この金属 Si が粒界第 2 相とし

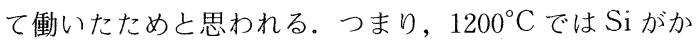
なり軟化し，その部分での粒界割れによるき裂成長のた

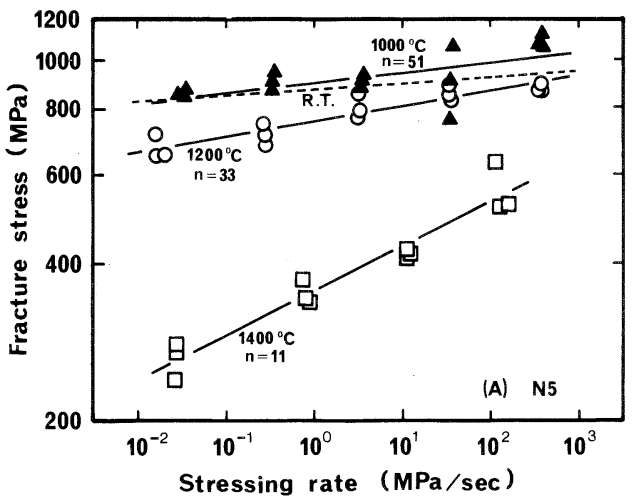

(A)

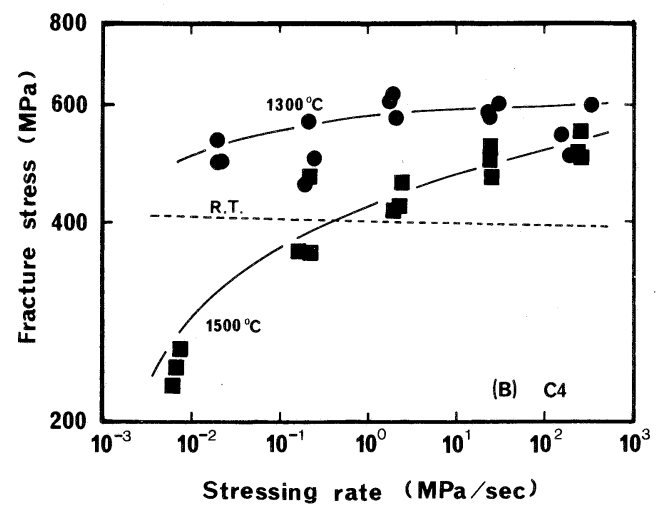

(B)

Fig.5. Results of dynamic fatigue tests in air. めに, 応力速度の遅い領域で強度が低下する. しかし, $1400^{\circ} \mathrm{C}$ になると Si が完全に融解した状態となり, Si が存在する部分は欠陥としてのみ働くために, 長時間負 荷によるき裂成長は認められないものの，強度が大きく 低下したと考えられる。

\section{2 大気中における動疲労特性}

$\mathrm{N} 5$ 及び C 4 の高温大気中での動疲労試験結果をそれ ぞれ図 $5(\mathrm{~A})$, (B) に示す。最初にN 5 の結果を真空 中での結果 (図 $1(\mathrm{E})$ ) と比較すると, $1200^{\circ} \mathrm{C}$ までの 温度域では両者の強度, 疲労指数はよく一致している. したがってこの試料の大気中におけるき裂成長も, 基本 的には粒界ガラス相の粘性低下による粒界割れが主因と 思われる. しかし $1300^{\circ} \mathrm{C}$ 以上の高温では両条件で大き な差を生じた. $1300^{\circ} \mathrm{C}$ 真空中の試験では応力速度の遅 い試験（クロスヘッド速度が $0.005 \mathrm{~mm} / \mathrm{min}$ 以下）が 試験片の変形のために困難であり， $1400^{\circ} \mathrm{C}$ になと試 料の分解が観察され, 試験が不可能であったのに対し,

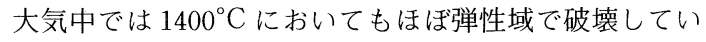
る.これは大気中の試験では, 試験片表面が酸化されて, 粒界ガラス相の特性が変化したためと思われる.N 5 の 高温における変形は基本的にはガラス相の粘性低下によ る粒界すべり, 粒界三重点におけるキャビティの発生と 


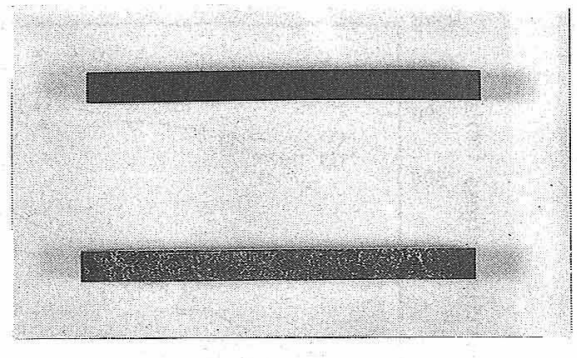

\section{Original specimen}

Fig. 6. Change of surface of C 4 specimen by heat treatment.
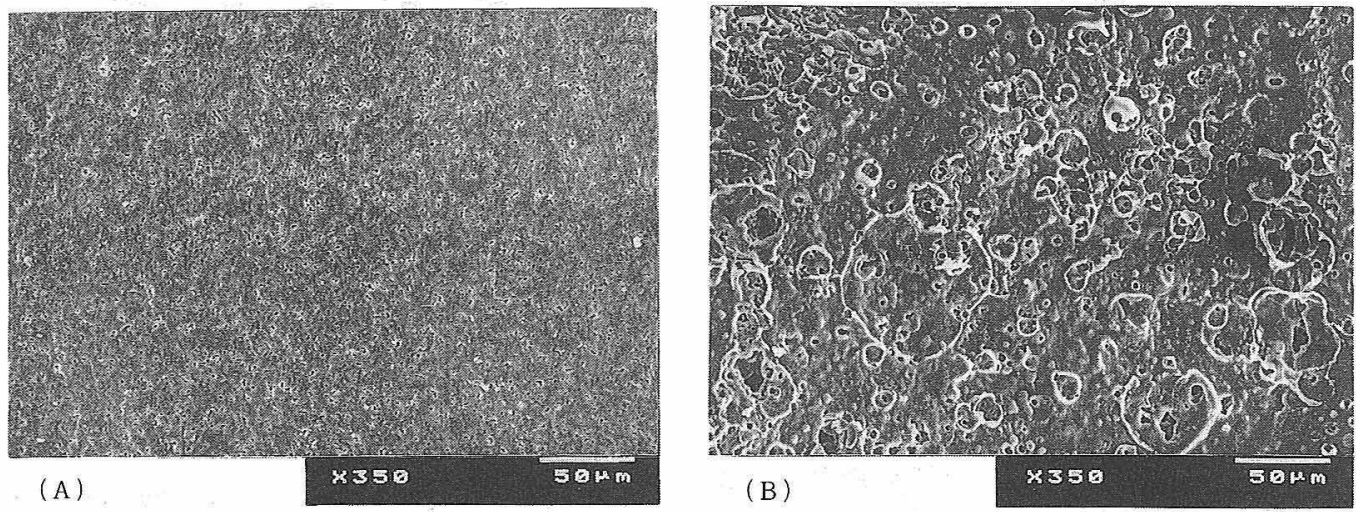

Fig. 7. Surfaces of $\mathrm{C} 4$ specimens failed by dynamic fatigue test with crosshead speed (A) $5 \mathrm{~mm} / \mathrm{min}$ and (B) $0.0005 \mathrm{~mm} / \mathrm{min}$ at $1500^{\circ} \mathrm{C}$ in air.

成長が原因と考えられるが6)，若井らはホットプレス窒 化ケイ素の表面が酸化されると内部のガラス相に含まれ る $\mathrm{Mg}, \mathrm{Ca}$ 等不純物イオンが表面酸化層に移動し,内 部のガラス相の粘性が高くなるためにクリープ特性が大 きく変化することを報告している7．今回試料として用 いたN 5 は,若井らの用いた試料と同一であり,したがっ て $1300^{\circ} \mathrm{C}$ 以上で観察された雲囲気による動疲労特性の 差も表面酸化とそれに伴う粒界ガラス相の特性変化によ るものと推察される.

次に C 4 の結果を真空中での結果（図 1（Ｉ））と比 較すると, 両者の動疲労特性は大きく異なった。つまり, 真空中では応力速度を遅くしても強度低下が認められ ず，この試料は高温で長時間負荷してもき裂成長をほと んど生じない材料と思われたが，大気中では低応力速度 領域において, $1300^{\circ} \mathrm{C}$ で若干量, $1500^{\circ} \mathrm{C}$ では大幅な強 度低下が認められた。この試料には粒界にガラス相がほ とんど存在せず，高温においても粒界割れによるき裂成 長はほとんど生じないと思われる.したがって大気中で の長時間負荷による強度低下は他の原因によるき裂成長 あるいはき裂成長以外の原因によるものと思われる．図 6 は C 4 試験片を $1500^{\circ} \mathrm{C}$ の大気に 20 時間さらしたと きの外観の変化を写真で示したものであるが，熱処理し た後の試験片表面には白い粉状の物質が多数付着し，表 面もかなりざらついている，この白い物質は赤外吸収ス
ペクトルの測定から，B-O , B-Si 結合を含むクリスト バライトと推察された。 $1500^{\circ} \mathrm{C}$ の試験において, ク口 スヘッド速度 $0.0005 \mathrm{~mm} / \mathrm{min}$ の条件で強度を測定した 場合, 負荷を開始してから破壊までの時間は約 10 時間 であるが, 大気中で試験を行った武験片表面には図 6 と 同様の変化が認められたのに対し，真空中で試験を行っ た試料には外観の変化が全く認められなかった。また $1500^{\circ} \mathrm{C}$ 大気中の試験でも, クロスヘッド速度が速い場 合には試験片に外観の変化はほとんど認められなかっ た. 図 7 は $1500^{\circ} \mathrm{C}$ 大気中, クロスヘッド速度 5 $\mathrm{mm} / \mathrm{min}(\mathrm{A})$ と $0.0005 \mathrm{~mm} / \mathrm{min}(\mathrm{B})$ の条件で武験した 試験片表面をSEM により観察したものであるが，(A) の表面には, 酸化層が認められないのに対し，(B) の 表面には，かなりの酸化層及び内部からガスが噴出した ような痕跡が認められる，図8(A)，(B) はそれぞれ 図 7 (A)，(B) の試験片表面近傍の破面を SEM により 観察したものである. 試験片 (A) の破壊起点は試験片 内部にあり, 表面には何の変化も認められないが, 試験 片 (B) の破壊起点は図 8 (B) に見られる表面欠陥であっ た. 試験片 (B) にはこのような空孔が各所に見られる. 以上の結果から，C4の長時間負荷に上る強度低下はき 裂成長が原因ではなく, 表面酸化による欠炛の発生が主 因之考えられる．このことを更に確かめるために，C4 武験片を $1500^{\circ} \mathrm{C}$ 大気中に 10 時間無負荷でさらし，そ 

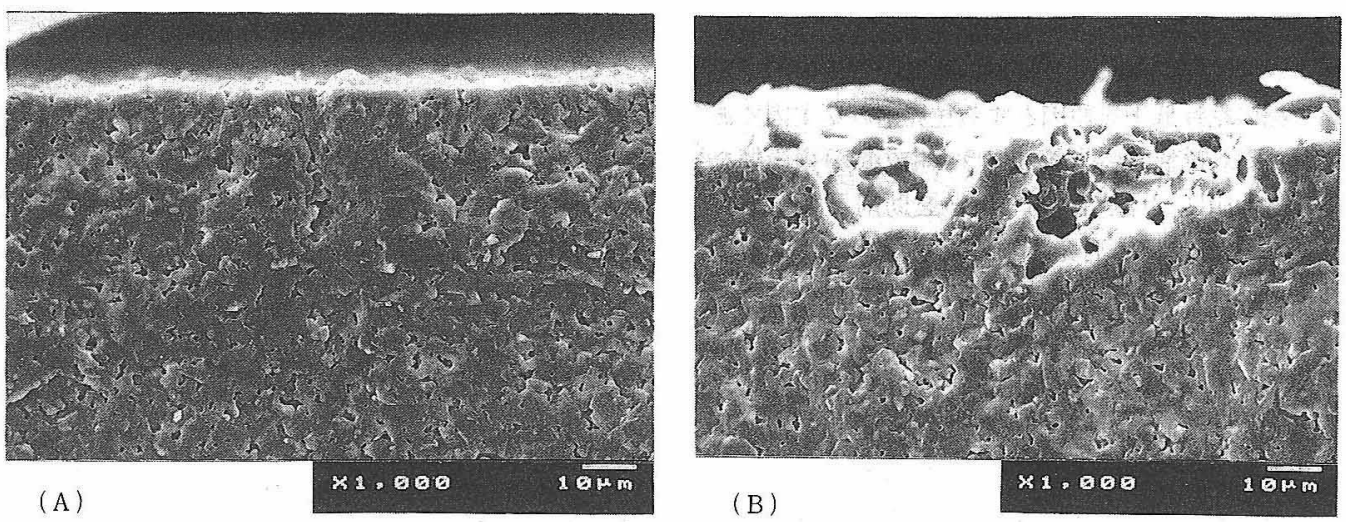

Fig. 8. Fracture surfaces of $\mathrm{C} 4$ specimens failed by dynamic fatigue test with crosshead speed (A) $5 \mathrm{~mm} / \mathrm{min}$ and (B) $0.0005 \mathrm{~mm} / \mathrm{min}$ at $1500^{\circ} \mathrm{C}$ in air.

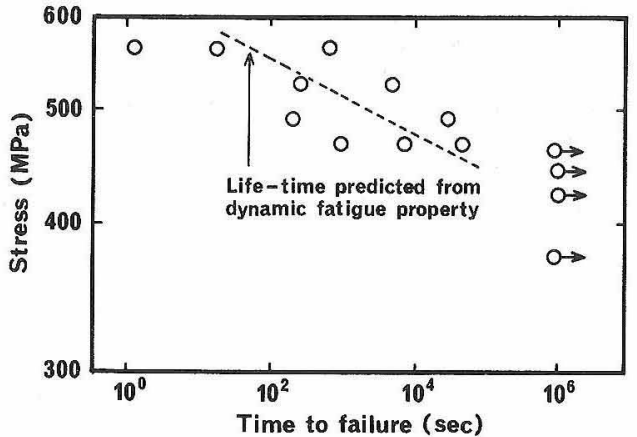

Fig. 9. Static fatigue behavior and predicted life-time from dynamic fatigue behavior of $\mathrm{N} 5$ at $1200^{\circ} \mathrm{C}$.

の後の $1500^{\circ} \mathrm{C}$ 大気中における 3 点曲げ強度をクロス ヘッド速度 $0.5 \mathrm{~mm} / \mathrm{min}$ の条件で測定した。 その結果, 無負荷で酸化した後の強度も約 $200 \mathrm{MPa}$ となり, 図 5 (B) におけるクロスヘッド速度 $0.0005 \mathrm{~mm} / \mathrm{min}$ の条件 で測定した強度とほぼ一致した。

以上のような表面酸化による欠陷の発生と，それに伴 う強度低下はN 5 では認められなかったが, その理由 として次のことが考えられる．N5には粒界にガラス相 が存在し, それが $1000^{\circ} \mathrm{C}$ 以上で軟化し始めるため, $1500^{\circ} \mathrm{C}$ では試験片が大きく変形して強度を測定するこ とが困難である，そのために今回の実験では試験温度を $1400^{\circ} \mathrm{C}$ 以下としたが，この温度域では試験片の表面酸 化が極端に進行することはなく,発生する欠陷も小さい， また，ガラス相の粘性低下による粒界割れき裂成長が活 発に起こるために，多少の表面欠陥が発生しても強度に 影響を与えない，これに対してC 4 では粒界にガラス 相がはとんど存在しないために，粒界割れによるき裂成 長がほとんど起こらず，酸化によって発生した表面欠陥 の影響がそのまま強度に現れたものと思われる。

\section{3 静疲労特性との比較}

N 5 試料について, 図 1 (E) の動疲労特性から一定 荷重下での寿命を予測し，実測静疲労特性と比較した。
図 9 は以前に報告した $\mathrm{N} 5$ の $1200^{\circ} \mathrm{C}$ における静疲労試 験結果である ${ }^{81}$. 静疲労試験の条件 (外部スパン $50 \mathrm{~mm}$, 内部スパン $30 \mathrm{~mm}$, 試料断面 $2 \mathrm{~mm} \times 4 \mathrm{~mm} の 4$ 点曲げ) が今回の動疲労試験条件と異なるため寿命予測を行う場 合には有効体積効果による初期き裂長さの違いを考慮し

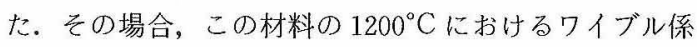
数は $m=20$ とした. 図 9 中に破線で示した直線が動疲 労特性から予測した静疲労寿命である. 実測寿命は，ほ ぼこの直線に沿って分布しており，寿命のばらつきを考 えると両者は比較的よく一致している．静疲労特性との 比較が，N 5 試料についてのみであるために断定はでき ないが，この結果から静的な荷重下での寿命は，動疲労 特性から推定可能と思われる, このことは動疲労特性が 静的な応力下でのゆっくりとしたき裂進展特性を十分に 反映していることを示している.

セラミックスの高温における遅れ破壊は, 基本的には 粒界ガラス相の軟化によるき裂成長が主因と考えられる が，ガラス相がある程度軟化すると，その粘弾性的な性 質がき裂進展特性に影響を与えることが予想される，例 えば, 応力速度が比較的速い繰り返し疲労や, 極端にき 裂進展速度が速い領域では，き裂進展に対する抵抗が変 化する可能性がある. 動疲労試験も応力值が変化する試 験方法なので, その影響が予想されるが, 今回の試験で は応力速度が比較的遅いためにき裂の成長が応力の変化 に十分対応できた．動疲労や静疲労で問題となるき裂成 長の速度がゆっくりとしている等の理由により, き裂進 展特性に対する応力速度の影響を無視できたのではない かと思われる。

\section{4. まとめ}

5 種類の窒化ケイ素及び 4 種類の炭化ケイ素セラミッ クスの動疲労試験を $800^{\circ} \sim 1500^{\circ} \mathrm{C}$ の真空中で行った。 また，一部の試料については大気中でも同様の試験を 行った。 その結果, 次の結論を得た。 
（1）粒界にガラス相が存在するセラミックスの高温 におけるき裂成長は, 真空中においても大気中において もガラス相の粘性低下を原因とする粒界割れが主因であ る. また，その高温疲労指数はガラス相の成分の影響を 受ける.今回用いた試料では $\mathrm{MgO}$ を助剂としたセラ ミックスのき裂成長が活発であったが，これは $\mathrm{Mg}$ が ガラス相の粘性を低下させることが原因と思われる.

（2）粒界にガラス相がほとんゼ存在しない反応焼結 窒化ケイ素あるいは $\mathrm{B}, \mathrm{C}$ 系ホットプレス炭化ケイ素 では高温においてもほとんよ゙き裂成長を生じない。

（3）金属 Si が多量に残留する反応焼結炭化ケイ素 では $1200^{\circ} \mathrm{C}$ で $\mathrm{Si}$ の粘性低下による粒界割れを原因と すると思われるき裂成長が認められるが， $1400^{\circ} \mathrm{C}$ では， Si が完全に融解するためにき裂成長は認められず大幅 な強度低下のみが観察される。

(4) $\mathrm{Al}_{2} \mathrm{O}_{3}, \mathrm{Y}_{2} \mathrm{O}_{3}$ 系ホットプレス窒化ケイ素では, 表面酸化により内部がラス相の粘性が増加し, 変形特性 が改善される。

（5） B，C系ホットプレス炭化ケイ素では，酸化に
より多数の空孔が試験片表面に発生し，強度が大きく低 下する。

また，N 5 試料について，動疲労特性から推定した一 定荷重下での寿命と，実測静疲労を比較したところ，両 者は比較的よく一致した。したがって高温静疲労寿命は 動疲労特性から推定可能と思わ机る。

謝辞 本研究を行うに当たり, 試料を提供して頂いた旭 硝子 (株) ・ 菅野隆志氏に深く感謝致します. また, 試料の化学 分析を行って頂いた名古屋工業技術試験所・石塚紀夫氏，柘植 明氏に深い謝意を表します。

\section{文献}

1）山内幸彦他，七ラミックス論文誌，96，885-89 (1988).

2) M. Kawai et al., Fract. Mech. Ceram., 6, 587-601 (1981).

3) T. Fett et al., Int. J. Fract., 36, 3-14 (1988).

4）阪口修司, 村山宣光, 若井史博, 窯協, 95, 1219-22 (1987).

5）幾原雄一, 栗下裕明, 吉永日出男, 窯協, 95, 638-45(1987).

6）大司達樹, 酒井清介, 伊藤 勝, 山内幸彦, 兼松 渉, 伊藤正治, 窯協, 94, 536-37 (1986).

7) F. Wakai et al., Proc. Int. Symp. Ceram. Compo. Eng., 279-85 (1983).

8）山内幸彦他，第 39 回名古屋工業技術試験所研究発表会予 稿集 (1985) pp.79-80. 